\title{
ПРОБЛЕМА СПРАВЕДЛИВОСТІ ТА ПІДХОДИ ДО ÏÏ ВИРІШЕННЯ
}

\section{І.В. Вілента}

Швидкі соціальні та технічні зміни у сучасному суспільстві породили низку проблем, які суттєво впливають на життя суспільства в цілому. Йдеться про кризу економічну, кризу політичної влади, проблему національно-культурної ідентичності, релігійні, релігійно-етнічні конфлікти, конфлікти цивілізацій, проблеми біомедичної етики, екологї, гендерні проблеми тощо. Поєднує всі ці проблеми те, що вони постають як актуальні моральні проблеми. Усталені способи їх вирішення не можуть задовольнити учасників суспільних процесів з огляду на взаємне визнання справедливості результатів, які можуть бути потенційно досягнуті. Диференціація та узагальнення дискурсів справедливості дозволить забезпечити, в межах спільної діяльності, раціонально-логічну легітимацію дій суб'єктів, які належать до різних соціальних груп (професійних, політичних, релігійних, етнічних), а також тим, хто діє у різноманітних сферах соціального та приватного життя.

Проблема справедливості- одна із найважливіших проблем сучасної західної філософіï. Ї̈̈ фундаментальну значущість демонструє відомий вираз теорії справедливості Дж. Ролза про те, що вона «є щонайпершою чеснотою суспільних інституцій, достоту як істина для філософських проблем» [5, с.26]. Проблема справедливості і соціальної справедливості зокрема-це не лише категорія етики, але й правової, соціально-політичної та економічної свідомості. Тому останнім часом ця категорія досліджується, переважно, політологами, фахівцями з соціальної та політичної філософії. Передусім, це знаходить своє розкриття у західноєвропейських авторів. Зокрема, варто зазначити ліберальні теорії справедливості Дж. Ролза, Ф.фон Хайєка, концепції

Актуальні проблеми духовності 
представників німецької комунікативної філософії П. Рікера, В. Хьосле, «етику дискурса» Ю. Хабермаса. Але не зважаючи на відмінності вказаних концепцій щодо принципів організації процедур взаємного узгодження, результатом цих процедур стають норми справедливості. У цьому контексті, однією із центральних проблем $\epsilon$ проблема інституціалізації тих норм, які будуть визнані. Так, зокрема, Ю. Хабермас висуває у якості необхідної умови законної обов'язковості моральних норм, визнання цих норм з боку усіх особистостей за допомогою раціонально-комунікативно організованого дискурсу [2, с.72]. Механізм інституціоналізації справедливості здійснюється передусім через формально організовані публічно-правові демократичні процедури, які становлять основу сучасної держави, орієнтованої у моральному плані на вираження загального блага, котре через систему влади забезпечує стабільність відносин та взаємної координації діяльності індивидів. Саме держава повинна забезпечити два основних моменти стабільності відносин між індивідами, які відстоюють свої інтереси: повагу до власності інших (включаючи самого себе, що полягає у захисті індивіда від зазіхань збоку інших, в тому числі й стосовно вибору власної системи цінностей, та виконання прийнятих на себе обов'язків (договору/угоди). Це саме ті умови, цінність яких є об'єктивною умовою будь-яких договірних відносин, в силу чого вони визнаються моральними цінностями сучасного суспільства. Слід зауважити, що власне система публічно-правової сфери реалізації справедливості передбачає, що закладені в її підгрунті цінності й принципи (передусім це різноманітні декларації, зокрема Декларація прав людини $\mathrm{OOH}$, зафіксовані у національних конституціях права та свободи тощо) $е$ критеріями справедливості для всіх законів, які приймаються, та дій як самої держави, так і всіх її громадян.

Складність проблеми інституалізації дискурсів (принципів) справедливості на сучасному етапі розвитку етичного знання багато в чому обумовлена і власне кризою ліберального уявлення про справедливість, яка передбачає її лінійну інтерпретацію. Розглянуті погляди на справедливість були засновані на ідеалі системного принципу «класичної раціональності» з іï̈ пошуком єдиної універсальної картини світу, яка знаходила своє застосування як у суспільно-політичних, так і етичних теоріях. У другій половині XX ст. основні логіко-методологічні передумови цієї моделі були піддані сумніву. Йдеться не лише про «постмодерніську деконструкцію», але й про посткласичну філософію науки (концепції «наукової парадигми» Т. Куна, «дослідницьких програм» І. Лакатоса тощо). Все більше знаходить підтримку думка про 
те, що не існує єдино істинної картина світу, а наше знання - це лише сукупність локальних картин світу. Аналогічні зміни відбуваються і у межах аналізу проблеми справедливості, тобто змінюється ставлення до пошуку універсальних передумов справедливого суспільства.

Таким чином, ця ситуація вимагає міжкультурного дискурсу справедливості, розробки принципів універсальної справедливості (моралі) у доповнювальності з аналізом різних життєвих практик [1, с. 355].

Зміст універсальної справедливості становлять:

1. Вимога рівності: діяти однаково в однакових умовах, тобто вимога неупередженості та заборона свавілля.

2. Ідея взаємозалежності вчинку та відплати за нього, що виражається у «золотому правилі моральності».

3. Вимога рівноваги між втратою та отриманням (набуттям), тобто справедливість обміну.

Обгрунтування універсальної справедливості видається можливим з огляду на те, що людство являє собою певну єдину моральну спільноту, основу якої складають єдині для всіх антропологічні факти. Тобто, з одного боку, в умовах обмеженості матеріальних ресурсів свобода людей призводить до конкуренції та конфліктів. А з іншого боку, наявність розуму і здатності домовлятись створює можливість об'єднання людей на підставі досягнення консенсусу.

Проте, як зазначає А.Єрмоленко, труднощі, що виникають в обгрунтуванні етики, яка була б універсально значущою і до того ж загальнообов'язковою для різноманітних етносів, націй та культур, призводять до того, що багато дослідників, наприклад Е. Макінтайр, Р.Рорті, М.Фуко, Р.Бубнер, В.Клюксен та ін. відходять від універсальних норм, надаючи перевагу різноманітним етносам та цінностям соціокультурних форм життя [2, с. 17]. Так, зокрема, на особливу увагу заслуговують праці Е. Макінтайра, ім'я якого пов'язують не лише з обгрунтуванням етики комунітаризму, але й з відродженням етики доброчинностей (чеснот). Е. Макінтайр доводить, що люди у сучасному світі живуть згідно різноманітним і численним фрагментованим життєвим практикам, застосовуючи одночасно різноманітні уявлення для конкуруючих і несумісних соціальних ідей і політик. I кожна 3 цих практик культивує власну систему чеснот, включаючи й чесноти справедливості [3, с. 26, 48].

На переконання Р. Рорті-ідея справедливості може обговорюватись лише в межах певної культури, не може бути універсальних стандартів справедливості, для кожної традиції вони культурно та історично обумовлені. Сучасне суспільство $є$ динамічним, воно передбачає 
як можливість вільного переходу людини від однієї спільноти до іншої, так і зміну своїх життєвих практик, пов'язаних з уявленнями про благо і справедливість власних дій. Тому актуальним, з нашої точки зору, є формалізація дискурсу, що враховує багатоманітність вихідних цінностей і принципів.

Справедливість уособлює можливість ідеалу як цінності, що обумовлений власною поведінкою людей, а також їхньою розумністю, тобто здатністю не лише формулювати кінцеву мету, але й надавати обгрунтування власним бажанням, рішенням, а також тверезо обмірковувати події, у які вони втягнуті. Отже, справедливе пов'язане із розумовою діяльністю. Справедливість - це «розумна цінність», котра осягається дискурсивним шляхом, і саме тоді, коли людина розуміє своє місце у суспільстві, шукає своє місце у соціально-історичному просторі і часі. Тобто ця цінність $є$ істотною для самосвідомого суб'єкта 3 досить чіткими соціальними переконаннями.

Принаймні усе, що здатне «виправдовуватись» розумом, може бути охарактеризоване як справедливе. Розумні докази у моральному вихованні часто бувають сильнішими за позитивні чи негативні факти. Мораль являє собою не лише вчинки, це ще й спосіб вираження, побудова міркувань, характер аргументів. Ідея справедливості завжди була найтіснішим чином пов'язана із розгорнутими обгрунтуваннями індивідуальних і колективних дій.

У структурі справедливості виділяють дві складові: 1) постійна (беззаперечна або формальна) вимагає «тлумачити однакові випадки однаково, різні-по-різному, тобто у кожному випадку виходити із однієї і тієї ж позиції; 2) перемінна (дискусійна), або реальна справедливість. Справедливість є моральною категорією і цінністю, і при цьому вона займає пріоритетне місце у критичній оцінці (легітимації) правових інститутів. Саме тому стверджують, що закон $є$ гарним (хорошим) тому, що є справедливим, а не закон справедливий тому, що він хороший. У розвитку правових основ справедливості етичні цінності незмінно відіграють роль кінцевих орієнтирів, що мають забезпечити послідовність та гуманістичну спрямованість цього розвитку. У такій інтерпретації справедливість - це логічна оцінка дій згідно критеріїв, зафіксованих у загальноприйнятій обов'язковій нормативній системі. Таким чином, справедливість визнається найбільш соціальною і найбільш правовою серед усіх чеснот.

Справедливість також застосовується до проблеми розподілу благ чи тягот (розподільча справедливість), а також до питань компенсації у процесі обміну, включаючи компенсацію за здійснену шкоду (урів- 
нююча справедливість). Принципом першої є теза: «кожному - належне, кожному - своє», принципом другої: «кожному рівну частину» (за Дж. Ролзом).

Призначенням справедливості є підтримання і відтворення рівноваги чи рівної міри. Її застосовують як для критичної оцінки людської поведінки, так і для оцінки інститутів. Шоразу, говорячи про справедливість як таку, а не маючи на увазі певну чесноту, розуміється існування певного балансу добра та зла всередині соціуму, підтримка якого життєво необхідна, а зруйнування означає руйнацію власне соціуму. Ця міра і являє собою справедливість у їі найширшому розумінні. Тому справедливість як норма (або, навіть, система норм) являє собою збереження соціальної інтеграції у межах того, що Т. Парсонс назвав соцієтальним співтовариством, тобто інтегративним ядром будь-якого соціуму [4, с. 43].

Можна говорити про те, що серцевиною соцієтального співтовариства $є$ відносини обміну, розподілу і відплати. Будь-яке суспільство можна уявити, як механізм, котрий забезпечує обмін, розподіл та відплату за добро і зло між своїми членами, здійснюючи таким чином їхню інтеграцію. Дії або бездіяльність кожного можуть або сприяти, або загрожувати інтеграції на підставі відомої усім міри, й оцінюються вони, відповідно, або як справедливі, або несправедливі. Таким чином, аналіз предмету справедливості передбачає звернення до аналізу суспільних відносин обміну, розподілу та відплати.

Сучасне демократичне суспільство характеризується як система формально організованих прав-свобод. Змістом його $є$ індивідуальна свобода у здійсненні своїх прав, а також публічне забезпечення й захист їх з боку різноманітних соціальних інститутів (передусім держави). Індивідуальна свобода у цьому контексті передбачає рівність можливостей індивідів щодо реалізації своїх невід'ємних прав. Це знайшло вираз в ізономній системі «прав людини» (єдиних для всіх людей, незалежно від їхньої національної, релігійної, расової, статевої, культурної приналежності, тобто таких, що мають суб'єктом свого застосування людину взагалі, абстрактного індивіда), а також у концепції правової держави, яка передбачає принципову рівність усіх перед законом з точки зору права. Саме у цьому контексті уявлення про справедливість інтерпретується як взаємне узгодження інтересів індивідів щодо реалізації їхніх прав та свобод.

Таким чином, угода, договір (договірні відносини) - це єдине джерело і основа справедливості. Усе, що відповідає укладеному договору - справедливо, та, власне, справедливість і є відповідність дого- 
вору. Звичайно, на початку XXI ст., концепції суспільного договору Т. Гоббса та Дж. Локка навряд чи можна розглядати як адекватні, але й сучасні теорії також базуються на схожих принципових засадах. Згідно сучасних варіантів «договірних» теорій, справедливість відносин між людьми, які визнаються раціонально діючими, рівними та вільними індивідами, забезпечується різноманітними засобами організації консенсусу на підставі взаємних поступок.

Отже, аналіз сучасних концепцій справедливості включає: 1) змістовні, тобто такі, що належать до договірних теорій (Дж. Ролз, Р. Нозік, О.Хьоффе). Ці теорії акцентують увагу переважно на питанні «що», тобто що таке справедливість і в чому полягають її критерії; 2) формальні (аналітичні) теорії переймаються питанням «як», досліджуючи логічні структури та мовні форми, що слугують для висловлювання справедливості (Х. Харт); 3) процедурні теорії намагаються виразити «що» через «як» (концепції Ю. Хабермаса та А. Кауфмана).

Дж. Ролз запропонував встановити два засадничих принципи справедливості. Перший принцип (рівної свободи) полягає у тому, що кожна людина обирає суспільство, яке зможе забезпечити їй максимальну індивідуальну свободу, оскільки власне така свобода є основним джерелом її соціальних сподівань і очікувань. Можемо його оцінити як принцип системи свобод. Основними свободами є, по-перше, принцип «рівної участі» у політичних процедурах, які визначаються конституцією, тобто політична свобода; по-друге, верховенство закону, або правова держава; по-третє, свобода совісті.

Другий принцип, який за своєю суттю містить у собі два принципи, формулюється так: «Соціальні та економічні нерівності повинні бути врегульовані таким чином, щоб вони призводили до найбільшої вигоди найменш успішних членів суспільства» (принцип диференціації (відмінності)) i «щоб пов'язані з ними суспільні посади були відкриті для усіх за умови чесного виконання рівності можливостей» (принцип рівних можливостей). Принципи справедливості Дж.Ролза спираються на стратегію, відому у теорії ігор як «maximin», яка передбачає максимізацію мінімального результату.

Теорія справедливості Р. Нозіка - «теорія вимог». Вимоги у сфері власності: 1) той, хто набув власність чесним шляхом, має на неї право; 2) право на власність має той, хто отримав її відповідно до принципу справедливої передачі майна від особи, якій майно належить по праву. О. Хьоффе створив концепцію «справедливості як обміну». Ї̈ї основний принцип полягає у рівноцінності отримання і втрати. Обмін-це не вузько економічне поняття, а демократична форма співробітництва. 
Який же критерій справедливості, запропонований тією чи іншою теорією є найбільш вдалим? Розуміння природи людини та основної політичної мети суспільства визначають вибір концепції справедливості. Якщо будь-яка концепція справедливості на інституціональному рівні виражає міру співвідношення свободи і рівності, то смисловим підгрунтям такого рішення є образ людини у їі найбільш фундаментальних якостях, тобто людина визнається як істота, здатна одночасно до самовдосконалення, так і істота автономна, розумна, здатна до самообмеження.

Існує думка, що оскільки у питаннях справедливості не вдається досягти переконань, які б поділялись абсолютно усіма, то необхідно задовольнятись тими, які поділяються більшістю. 3 цією метою існує представницька система з іï державно-правовими правилами гри, відповідним розподілом ролей і збереженням рольової дистанції. Методологічні засади для прикладної етики - як зробити пануючі уявлення про справедливість усвідомленими і можливими для застосування у конкретній ситуації.

Важливий прикладний аспект полягає також у питанні про те, чи належить справедливість до загальнолюдських цінностей, чи є принципи справедливості універсальними або ж питання про них повинно вирішуватись у межах кожної культури індивідуально. Йдеться не лише про національні та культурні особливості. Змінюється уявлення про суспільство як про дещо універсально єдине. Відповідно відбуваються зміни щодо єдиного й універсального критерію моральності. Мораль «розкладається» на сукупність «локальних» моралей (взаємопов'язаних, але відносно самостійних), що обумовлені різними культурними, національними, регіональними, соціальними особливостями буття людини. З'являється ідея про існування багатьох різновидів моралі, які в сукупності, при збереженні своєрідності, утворюють те, що і є власне мораль («багатоманітність у єдності»). Ці імпульси плюралізації різновидів моралі існують у середовищі поєднання життєвих та необхідних етичних принципів і цінностей на перетині культур і суспільств. Очевидно, що мирне та продуктивне співробітництво різноманітних людей та співтовариств людей може бути реалізованим лише за умови, що вони розуміють своє існування як взаємопов'язане та вмотивоване згодою щодо підвалин етичних цінностей та принципів.

Отже, ситуація, що виникла, потребує критичного аналізу системи моральних принципів і цінностей, а також напрацювання теоретичних підходів до обгрунтування їхніх змін, оскільки вирішення складних глобальних проблем можливе лише на підставі спільності етичних пра- 
ктик, розуміння спільного блага та уявлень про справедливість, що поділяються усіма. Без такого розуміння, заснованого, з одного боку, на рівності учасників діалогу культур, які забезпечують взаємну довіру, а з іншого боку, на визнанні наявних відмінностей, неможливе спільне продуктивне існування людей у сучасних умовах. Тому актуальною проблемою є дослідження дискурсів справедливості, що зробить можливим обгрунтування процедур справедливої соціальної організації. Вихід вбачається у сучасній німецькій комунікативній філософії з позиції етики дискурсу (К.-О. Апель, Ю. Хабермас).

Відповідно до позицій комунікативної філософії найвищою інстанцією суспільного життя $є$ аргументований дискурс, завдяки якому приймаються всі розумні рішення. Універсалістські принципи справедливості є важливими й виправданими для суспільства в цілому як умова збереження його ідентичності, що є можливим лише за умови визнання рівності культурних традицій та поваги до прав інших.

\section{1 Бібліографія}

[1] Anель K.-О. Етноетика та універсалістська макроетика: суперечність чи доповнювальність // Єрмоленко А.М. Комунікативна практична філософія. - К.: Лібра, 1999.

[2] Єрмоленко A.M. Комунікативна практична філософія. - К.: Лібра, 1999.

[3] Макинтайр А. После добродетели: Исследования теории морали. - М.: Академический Проект, 2000.

[4] Парсонс Т. Система современных обществ.-М.: Аспект-Пресс, 1998.

[5] Ролз Дж. Теорія справедливості. - К.: Основи, 2001. 